\title{
PENGARUH KONSENTRASI EKSTRAK KULIT BATANG MANGROVE (Avicennia marina) DALAM SEDIAAN KRIM TERHADAP SIFAT FISIK DAN AKTIVITAS ANTIBAKTERI Staphylococcus aureus
}

\author{
Eko Saputra $^{* 1}$, Lulu Setiyabudi ${ }^{2}$, Elisa Issusilaningtyas ${ }^{3}$ \\ 1,2,3 STIKES Al-Irsyad Al-Islamiyyah, Cilacap, Jawa Tengah, Indonesia \\ e-mail: ${ }^{* 1}$ ekosaputraco@gmail.com, ${ }^{2}$ 1.setiyabudi@gmail.com, ${ }^{3}$ elisa12211@gmail.com
}

\begin{abstract}
ABSTRAK
Mangrove api-api (Avicennia marina) merupakan bahan alam yang telah diteliti memiliki aktivitas sebagai antibakteri. Ekstrak mangrove Avicennia marina dapat digunakan sebagai penghambat pertumbuhan bakteri Staphylococcus aureus. Penelitian bertujuan untuk mengetahui pengaruh konsentrasi ekstrak kulit batang mangrove terhadap sifat fisik sediaan krim dan aktivitas antibakteri. Penelitian menggunakan metode eksperimental dengan variasi konsentrasi ekstrak 5\% (F1), 10\% (F2) dan 15\% (F3). Karakteristik fisik yang diamati berupa organoleptis, homogenitas, tipe krim, pH, viskositas, daya sebar, dan daya lekat. Uji aktivitas antibakteri terhadap Staphylococcus aureus menggunakan metode difusi sumuran. Analisis data dilakukan dengan menggunakan statistik. Hasil evaluasi fisik sediaan memiliki organoleptis krim berbau khas ekstrak kulit batang mangrove, krim berwarna putih kehijauan dengan tekstur halus dan homogen (F1), krim berwarna hijau dengan tekstur agak kasar (F2) dan (F3) tidak homogen. Sediaan krim mempunyai tipe krim M/A dengan pH 6. Uji viskositas sediaan krim memenuhi standar, uji daya sebar krim yang memenuhi syarat adalah (F1). Uji daya lekat krim yang memenuhi syarat adalah (F1) dan (F2). Hasil pengujian aktivitas antibakteri sediaan krim adalah diameter zona hambat bakteri pada (F1) 15,1 mm, (F2) 17,6 mm, dan (F3) 19,4 mm.
\end{abstract}

Kata kunci: Mangrove Avicennia marina, krim, Staphylococcus aureus

\section{ABSTRACT}

Mangrove fires (Avicennia marina) is a natural material that has been studied to have activity as an antibacterial. Avicennia marina mangrove extract can be used as a growth inhibitor of staphylococcus aureus bacteria. The research aims to determine the influence of mangrove bark extract concentration on the physical properties of cream preparations and antibacterial activity. The study used experimental methods with variations in extract concentrations of 5\% (F1), $10 \%$ (F2) and 15\% (F3). The observed physical characteristics are organoleptis, homogeneity, cream type, $\mathrm{pH}$, viscosity, spreadability, and adhesion. Test antibacterial activity against Staphylococcus aureus using well diffusion method. Data analysis is done using statistics. The results of physical evaluation of preparations have organolepty cream smells typical of mangrove bark extract, greenish-white cream with a smooth and homogeneous texture (F1), green cream with a slightly rough texture (F2) and (F3) is not homogeneous. Cream preparations have a cream type M/A with a $\mathrm{pH}$ of 6. The cream preparation viscosity test meets the standard, the eligible cream spread test is $(F 1)$. Eligible cream adhesion tests are $(F 1)$ and (F2). The test results of antibacterial activity of cream preparations are the diameter of the bacterial bland zone at (F1) $15.1 \mathrm{~mm}$, (F2) $17.6 \mathrm{~mm}$, and (F3) $19.4 \mathrm{~mm}$.

Keywords: Mangrove Avicennia marina, cream, Staphylococcus aureus 


\section{PENDAHULUAN}

Indonesia merupakan alah satu negara yang memiliki wilayah mangrove terbesar di dunia [1]. Menurut jurnal Mahmiah [2], tumbuhan mangrove di Indonesia merupakan yang terbanyak di dunia, baik dari segi jumLah spesies ( \pm 45 spesies) maupun kuantitas area $( \pm$ $42.550 \mathrm{~km} 2$ ).

Dalam penelitian prabu [3]. Avicennia marina atau biasanya disebut juga mangrove api-api dapat digunakan sebagai obat herbal karena memiliki senyawa bioaktif, antara lain antioksidan, antitumor, antiinflamasi, antialergi, antimikroba, antiageng, antikolinergik, antikonvulsan, antiarterokelorosis dan antituberkulin. Ekstrak Avicennia marina lebih efektif digunakan sebagai antibakteri dibandingkan anti jamur [4]. Mangrove api-api memiliki kandungan senyawa aktif yaitu glukosida, flavonoid, saponin, alkaloid, triterpenoid dan tanin [5].

Menurut jurnal Renaldi, Avicennia marina memiliki aktivitas sebagai antibakteri karena dapat menghambat pertumbuhan bakteri Staphylococcus aureus [6]. Staphylococcus aureus salah satu jenis bakteri gram positif yang dapat ditemukan padatangan, rambut, muka, dan saluran pernapasan. Pengobatan yang dapat dilakukan untuk mengatasi bakteri tersebut adalah penggunaan obat antibakteri [7]. Bioaktivitas senyawa bioaktif terhadap bakteri $E$. coli untuk jenis mangrove Avicennia marina lebih tinggi dibandingkan B. gymnorrhiza, terutama pada bagian batang $(25,28 \mathrm{~mm})$, akar sebesar $(19,11 \mathrm{~mm})$, dan daun $(14,11 \mathrm{~mm})$.

Dalam penelitian ini dibuat menjadi bentuk sediaan krim, penggunaannya relatif praktis dan mudah digunakan, serta sediaan krim memiliki fungsi untuk menghindari rasa lengket pada kulit sehingga pengguna merasa nyaman saat penggunaan. Beberapa penelitian telah dilakukan dalam pembuatan produk krim berbahan aktif alami.

Berdasarkan uraian pendahuluan, maka perlu dilakukan penelitian tentang kulit batang mangrove api-api yang memiliki aktivitas antibakteri yaitu dengan melihat pengaruh konsentrasi dalam sediaan krim terhadap sifat fisik dan aktivitas antibakteri Staphylococcus aureus.

\subsection{Alat dan Bahan}

\section{METODE PENELITIAN}

Alat yang digunkan dalam penelitiaan ini yaitu timbangan analitik, mortir, stemper, erlemeyer, autoclave, spatula, pinset, cawan petri, cawan proselen, tabung reaksi, water bath, batang pengaduk, corong, sudip, viskometer, inkubator, kompor listrik, pipet, sudip, jarum ose, $\mathrm{pH}$ meter dan alat gelas lainnya.

Bahan yang digunakan dalam penelitian ini adalah kulit batang mangrove, cera alba, asam stearat, TEA, vaselin putih, metil paraben, propilen glikol, aquades, etanol $96 \%$, media NA, bakteri staphylococus aureus, logam magnesium, reagen dragondroff, $\mathrm{H} 2 \mathrm{SO} 4$, $\mathrm{NaCl}, \mathrm{CH} 3 \mathrm{COOH}$, klorofom dan HCI.

\subsection{Jalannya Penelitian}

\subsubsection{Pengambilan Sampel}

Kulit batang mangrove diperoleh dengan cara membeli kepada pihak perhutani di wisata mangrove hutan payau di Kabupaten Cilacap.

\subsubsection{Determinasi tumbuhan}

Determinasi dilakukan untuk menentukan kebenaran sempel yang digunakan dalam penelitian. Determinasi kulit batang mangrove dilakukan di laboratorium Fakultas Biologi Universitas Jendral Soedirman Purwokerto.

\subsubsection{Pembuatan Simplisia}

Kulit batang mangrove dibersihkan dengan air mengalir sampai bersih, ditiriskan hingga kering, disimpan dalam wadah yang bersih. Selanjutnya dibuat menjadi 
simplisia dengan cara kulit batang mangrove dilakukan sortasi, perajangan, kemudian dilanjutkan dengan metode ekstraksi.

\subsubsection{Pembuatan Ekstrak Kulit Batang Mangrove Avicennia marina}

Kulit batang mangrove dilarutkan dengan menggunakan pelarut etanol selama 3 hari berturut - turut dan dilakukan pengadukan setiap 24 jam untuk mendapatkan hasil yang baik dengan pembanding 1:3. Setelah dimaserasi kemudian dilakukan penyaringan dengan kertas saring, setelah didapatkan kemudian diuapkan sampai mendapat ekstrak kental. Kemudian dilanjutkan dengan proses pembuatan sediaan krim.

\subsubsection{Penetapan Kadar Air}

Sebanyak 1 gr ekstrak ditimbang, Kemudian dikeringkan pada suhu $105 \circ \mathrm{oC}$ selama 60 menit. Pemanasan dilakukan hingga bobot tetap. Sampel yang sudah didapat bobotnya tetap yaitu sampai perbedaan penimbangan berturut-turut tidak lebih dari $0,25 \%$, kemudian dikeluarkan dari oven, dicatat bobot tetap yang diperoleh untuk menghitung presentase susut pengering [8].

\subsubsection{Skrining Fitokimia}

a. Uji Alkaloid

Sebanyak $5 \mathrm{~mL}$ ekstrak kental ditambahkan dengan $2 \mathrm{~mL} \mathrm{HCl}$, selanjutnya ditambahkan Reagen Dragendorff. Hasil ekstrak yang positif mengandung alkaloid akan menunjukkan perubahan warna merah atau orange [9].

b. Uji Terpenoid

Sebanyak $5 \mathrm{~mL}$ ekstrak kental ditambahkan dengan $2 \mathrm{~mL}$ kloroform dan $3 \mathrm{~mL}$ $\mathrm{H}_{2} \mathrm{SO}_{4}$. Proses penambahan dilakukan secara pelan dan hati-hati hingga terbentuk lapisan berwarna merah kecoklatan. Hasil perubahan warna yang sesuai menunjukkan positif adanya terpenoid [9].

c. Uji Saponin

Ekstrak kulit batang mangrove Avicennia marina dilarutkan dengan aquades. Pembentukan busa setinggi $1-10 \mathrm{~cm}$ yang setabil selama tidak kurang dari 10 menit, menunjukan adanya saponin [10].

d. Uji Flavonoid

Sebanyak $1 \mathrm{~g}$ sampel diekstraksi dengan $5 \mathrm{~mL}$ etanol. Selanjutnya tambahkan beberapa tetes $\mathrm{HCl}$ pekat dan 1,5 g magnesium. Positif adanya flavonoid ditandai dengan perubahan warna merah muda atau merah magenta dalam waktu 3 menit [11].

\section{e. Uji Tanin}

Sebanyak $1 \mathrm{~g}$ ekstrak kulit batang mangrove dilarutan dalam $5 \mathrm{~mL} \mathrm{FeCl}{ }_{3}$ dan diamati perubahan warna yang terjadi. Perubahan warna hijau hingga biru kehijauan menandakan positif adanya cathechic tannin atau biru kehitaman yang menandakan adanya gallic tannin [12].

\subsubsection{Formulasi Krim Antibakteri}

Tabel I. Formulasi sediaan krim

\begin{tabular}{|c|c|c|c|}
\hline \multirow{2}{*}{ Bahan } & \multicolumn{3}{|c|}{ Formulasi } \\
\cline { 2 - 4 } & F1 & F2 & F3 \\
\hline $\begin{array}{c}\text { Ekstrak kulit } \\
\text { batang mangrove }\end{array}$ & $5 \%$ & $10 \%$ & $15 \%$ \\
\hline Cera alba & 1 & 1 & 1 \\
\hline Asam stearate & 7,5 & 7,5 & 7,5 \\
\hline TEA & 0,75 & 0,75 & 0,75 \\
\hline Vaselin putih & 4 & 4 & 4 \\
\hline Metil paraben & 0,6 & 0,6 & 0,6 \\
\hline Propilen glikol & 44 & 4 & 4 \\
\hline Akuades ad & $50 \mathrm{ad}$ & $51 \mathrm{ad}$ & $51 \mathrm{ad}$ \\
\hline
\end{tabular}




\subsubsection{Evaluasi Sifat Fisik Krim}

\section{a. Uji Organoleptis}

Sempel dioleskan pada bagian lempeng kaca yang rata, kemudian dilakukan pengamatan secara visual, apabila sediaan tersebut memiliki warna yang merata tidak terjadi pemisahan dan pemecahan maka sediaan tersebut bisa dikatakan homogen.

b. Homogenitas

Pengujian homogenitas dengan cara sejumlah krim yang akan damati dioleskan pada kaca objek sehingga membentuk lapisan tipis, kemudian ditutup menggunakan kaca preparat. Krim yang dinyatakan homogen apabila pada pengamatan krim mempunyai tekstur tampak rata dan tidak menggumpal [13].

\section{c. Uji Tipe Krim}

Pengujian bertujuan untuk memastikan tipe emulsi yang dibuat sesuai dengan tipe emulsi yang diharapkan. Sebanyak 1 tetes sediaan krim ditempatkan diatas gelas objek, ditambah 1 tetes larutan metilen biru, dicampur merata, diamati dibawah mikroskop, jika terjadi warna biru homogen pada fase luar, maka tipe emulsi adalah minyak dalam air (M/A) [14].

\section{d. $\mathbf{U j i} \mathbf{p H}$}

Tujuan dari pengujian $\mathrm{pH}$ yaitu mengetahui nilai asam basa sediaan krim yang aman dan dapat digunakan dalam penggunaan luar. Adapun $\mathrm{pH}$ yang disyaratkan dalam pembuatan sediaan topikal yaitu berkisar antara 4,5-6,5.

\section{e. Uji Viskositas}

Uji viskositas krim dilakukan dengan bantuan alat Viskometer. Mekanisme kerjanya, rotor mulai berputar dan jarum penunjuk viskositas secara otomatis akan bergerak menuju ke kanan kemudian setelah stabil. Viskositas dibaca pada skala dari rotor yang digunakan. Satuan yang digunakan menurut JLS 28809 standar viskositas yang telah dikalibrasi adalah desipaskal-second (dPas-s) [15].

\section{f. Uji Daya Sebar}

Sebanyak $0,5 \mathrm{~g}$ krim diletakan ditengah media kaca, ditutup dengan kaca lain yang sudah ditimbang beratnya, dan dibiarkan selama 1 menit kemudian dilakukan pengukuran daya sebar. Selanjutnya, ditambahkan beban $50 \mathrm{~g}$ dibiarkan selam 1 menit dan dilakukan pengukuran daya sebarnya. Proses uji dilakukan berulang hinga didapatkan diameter yang cukup untuk melihat pengaruh beban terhadap perubahan diameter pada sediaan krim kulit batang mangrove.

\section{g. Uji Daya Lekat}

Sebanyak 0,5 g krim diletakan pada media kaca dan ditekan dengan beban 1 $\mathrm{kg}$ selam 5 menit. Kemudian objek dipasang pada alat tes yang diberi beban $80 \mathrm{~g}$ dan dicatat waktu pelepasan krim. Dilakukan pengujian sebanyak 3 kali.

\subsubsection{Uji Aktivitas Antibakteri}

\section{a. Penyimpanan Alat dan Sterilisasi}

Alat yang akan digunakan disterilkan terlebih dahulu. Alat seperti beaker glass, gelas ukur, erlenmeyer dan karet pipet dibungkus dan selanjutnya disterilkan didalam autoklaf pada suhu $121^{\circ} \mathrm{C}$ selama 15 menit. Sedangkan alat seperti batang pengaduk, pinset, spatula, gelas arloji yang sudah dibungkus dimasukkan dalam oven pada suhu $160-170^{\circ} \mathrm{C}$ selama \pm 2 jam. Pada jarum ose dan pinset dibakar dengan pembakaran diatas api bunsen [12].

\section{b. Pembuatan Media Nutrien Agar}

Sebanyak 7, 25 gr nutrient agar disuspensikan dalam $250 \mathrm{~mL}$ aquades steril, kemudian dimasukan kedalam labu erlenmeyer dipanaskan menggunakan hotplate selama \pm 10 menit hingga larut. Kemudian disterilkan dengan autoklaf pada suhu $121^{\circ} \mathrm{C}$. Media yang sudah steril, dituangkan dalam kondisi hangat $\left(40^{\circ} \mathrm{C}-45^{\circ} \mathrm{C}\right)$ kedalam cawan petri. Media nutrien agar yang telah dituangkan kedalam cawan petri dibiarkan hingga memadat. 


\section{c. Pembuatan Standar Mc Farland}

Sebanyak 9,95 mL larutan $\mathrm{H}_{2} \mathrm{SO}_{4} 1 \%$ dicampurkan dengan larutan $\mathrm{BaCl}_{2} \cdot 2 \mathrm{H}_{2} \mathrm{O}$ $1,175 \%$ sebanyak $0,05 \mathrm{~mL}$ dalam erlenmeyer. Kemudian digojok sampai terbentuk larutan yang keruh. Kekeruhan ini dipakai sebagai standar kekeruhan suspensi bakteri uji.

\section{d. Pembuatan Suspensi Bakteri}

Hasil inokulasi bakteri Staphylococcus aureus dimasukkan kedalam tabung reaksi dengan kawat ose steril yang berisi $2 \mathrm{~mL} \mathrm{NaCl} 0,9 \%$ kemudian dihomogenkan dan dibandingkan dengan kekeruhannya.

\section{e. Uji Aktivitas Antibakteri}

Pengujian aktivitas antibakteri dilakukan dengan menggunakan metode sumuran. Kontrol bakteri yang digunakan adalah bakteri Staphylococus aureus. Dibuat media nutrient agar steril kemudian diamkan sampai mengeras. Selanjutnya dibuat sumuran (well) dengan menggunakan bor gabus pada cawan petri dengan diameter kurang lebih $8 \mathrm{~mm}$. Dalam satu cawan petri dapat berisi 4 sumuran dengan jarak sumuran yang telah diatur. Selanjutnya, dimasukan formulasi sedian krim kulit batang mangrove yang sudah diformulasikan. Kemudian dimasukan kedalam lemari inkubator selama 24 jam dalam suhu $37{ }^{\circ} \mathrm{C}$. Selanjutnya dilakukan penghitungan diameter zona hambat dan ditentukan makanakah formulasi yang sesuai.

\subsection{Teknik Pengumpulan Data Dan Analisa Data}

Teknik pengumpulan data pada penelitian ini dilakukan dengan mencatat hasil pengamatan dari penelitian yang dilakukan menggunakan analisis data deskriptif. Serta dilanjutkan dengan uji One-Way ANOVA terhadap sifat fisik dan aktivitas antibakteri.

\section{HASIL DAN PEMBAHASAN}

\subsection{Pengambilan Sampel}

Tanaman yang dimanfaatkan sebagai bahan aktif pembuatan sediaan krim yaitu tanaman mangrove Avicennia marina. Bagian yang diambil yaitu bagian kulit batang yang masih muda pada bagian ranting pohon. Pengambilan kulit batang dilakukan di wisata hutan payau kabupaten Cilacap oleh pihak pengelola hutan.

\subsection{Determinasi}

Pengujian determinasi tumbuhan merupakan tahap awal untuk mengidentifikasi kebenaran tumbuhan yang akan digunakan pada penelitian. Pengujian determinasi tumbuhan kulit batang mangrove Avicennia marina dilakukan menggunakan metode studi referensi. Penetapan dilakukan dengan membandingkan kesesuaian ciri-ciri morfologi dan makroskopis dari kulit batang mangrove Avicennia marina terhadap kepustakaan yang tersedia. Karakteristik dari kulit batang mangrove Avicennia marina sesuai dengan morfologi tanaman yang digunakan dalam penelitian, sehingga dapat disimpulkan bahwa tanaman Avicennia marina yang digunakan dalam penelitian ini adalah benar Avicennia marina.

\subsection{Pembuatan Simplisia Dan Ekstraksi Kulit Batang Mangrove Avicennia marina}

Kulit batang mangrove diiris kecil-kecil yang bertujuan untuk memaksimalkan pengambilan zat aktif saat proses maserasi dan kulit batang mangrove tanpa dilakukan proses pengeringan. Kulit batang mangrove diekstrak dengan menggunakan metode maserasi dengan menggunakan pelarut etanol 96\% dengan perbandingan 1:3. Proses maserasi dilakukan selama 3 hari proses maserasi dan 3 hari selanjutnya dilakukan remaserasi dengan dilakukan pengadukan. proses pengadukan bertujuan untuk 
mempercepat dan memaksimalkan hasil maserasi. Selanjutnya dilakukan proses hingga menghasilkan ekstrak kental. Tujuan dari penguapan untuk memisahkan ekstrak dari pelarut dengan pemanasan [16]. Kulit batang mangrove yang dimasukan sejumLah 500 gr dengan menggunakan pelarut etanol $96 \%$ sebanyak 1,5 liter menghasilkan ekstrak kental yang sudah ditimbang sebanyak 39,41 gr dan rendemen diperoleh hasil sebesar 7,88\%.

\subsection{Penetapan Kadar Air}

Penetapan kadar air bertujuan untuk menetapkan residu air setelah proses pengeringan. Syarat mutu kadar air dalam simplisia yaitu < 10\% [17]. Sebanyak $1 \mathrm{~g}$ ekstrak dikeringkan pada suhu $105^{\circ} \mathrm{C}$ selama 60 menit. Dari hasil uji penetapan kadar air diperoleh hasil 0,92 g maka ekstrak kulit batang mangrove Avicennia marina memenuhi persyaratan uji kadar air dengan hasil persentase yang diperoleh $8 \%$.

\subsection{Hasil skrining fitokimia}

Hasil skrining fitokimia yang terdapat dalam ekstrak mangrove Avicenia marina dapat dilihat pada tabel II.

Tabel II. Hasil Skrining Fitokimia Ekstrak Kulit Batang avicennia marina.

\begin{tabular}{|c|c|c|c|c|}
\hline Uji fitokimia & Pereaksi & $\begin{array}{c}\text { Standar } \\
\text { warna }\end{array}$ & Hasil & Keterangan \\
\hline 1. Alkaloid & $\begin{array}{c}\mathrm{HCl} \text {, Reagen } \\
\text { Dragendroff }\end{array}$ & $\begin{array}{c}\text { Orange / } \\
\text { Merah }\end{array}$ & + & Orange \\
\hline 2. Terpenoid & Kloroform, $\mathrm{H}_{2} \mathrm{SO}_{4}$ & $\begin{array}{c}\text { Merah } \\
\text { Kecoklatan }\end{array}$ & + & Merah \\
\hline 3. Saponin & Ditambahkan Air Panas & Berbusa & + & $\begin{array}{c}\text { Menimbulkan } \\
\text { busa }\end{array}$ \\
\hline 4. Flavonoid & logam $\mathrm{Mg}, \mathrm{HCl}$ pekat & $\begin{array}{c}\text { Merah / } \\
\text { Jingga }\end{array}$ & - & $\begin{array}{c}\text { Bening } \\
\text { kehijauan }\end{array}$ \\
\hline 5. Tanin & $\mathrm{FeCl}_{3}$ & Hijau / biru & + & Hijau \\
\hline
\end{tabular}

Keterangan: (+) positif : Terdeteksi mengandung senyawa

(-) negatif : Terdeteksi tidak mengandung senyawa.

Skrining fitokimia dilakukan untuk mengetahui ada atau tidaknya senyawa bioaktif yang terdapat dalam ekstrak kulit batang mangrove Avicennia marina. Hasil skrining tersebut digunakan untuk mengetahui senyawa bioaktif mana yang dapat digunakan sebagai antibakteri.

\subsection{Formulasi}

Pembuatan krim dari kulit batang mangrove Avicennia marina dilakukan dengan beberapa tahapan. Tahapan yang pertama dengan penentuan basis krim dengan bahan yang sudah ditentukan. Tahap kedua setelah terbentuknya krim dilakukan evaluasi fisik krim dengan parameter yang meliputi sifat fisik seperti organoleptis, homogenitas, $\mathrm{pH}$, tipe krim, viskositas, daya lekat dan daya sebar. Variasi dilakukan menjadi beberapa formulasi yaitu kontrol negatif (-) merupakan basis krim, F1 dilakukan dengan penambahan ekstrak mangrove sebesar 5\%, F2 penambahan ekstrak mangrove sebesar 10\% dan F3 dengan penambahan ekstrak mangrove paling banyak sebesar $15 \%$.

\subsection{Evaluasi Sifat Fisik Krim \\ 3.7.1. Organoleptik}


Uji organoleptik dilakukan untuk mengetahui bau, warna dan tekstur dari krim sediaan ekstrak mangrove Avicennia marina yang diamati secara visual. Hasil uji organoleptik dari krim dapat dilihat pada tabel III.

Tabel III. Hasil Uji Organoleptik Krim Ekstrak Mangrove Avicennia marina.

\begin{tabular}{ccccc}
\hline Formulasi & Replikasi & Bau & Warna & Tekstur \\
\hline F1 & 1 & Khas krim & Putih kehijauan & Halus \\
& 2 & Khas krim & Putih kehijauan & Halus \\
& 3 & Khas krim & Putih kehijauan & Halus \\
F2 & 1 & Khas krim & Hijau & Agak kasar \\
& 2 & Khas krim & Hijau & Agak kasar \\
& 3 & Khas krim & Hijau & Agak kasar \\
F3 & 1 & Khas krim & Hijau & Kasar \\
& 2 & Khas krim & Hijau & Kasar \\
& 3 & Khas krim & Hijau & Kasar \\
\hline
\end{tabular}

\footnotetext{
Keterangan :

F1 : Formulasi dengan penambahan ekstrak 5\%

F2 : Formulasi dengan penambahan ekstrak 10\%

F3 : Formulasi dengan penambahan ekstrak 15\%
}

Pengujian organoleptik pada sediaan krim pada tiap pengulangan memiliki bau khas pada ekstrak kulit batang mangrove dan berwarna putih, putih kehijauan dan hijau. Bau dan warna yang dihasilkan berasal dari ekstrak kulit batang mangrove Avicennia marina. Terjadinya perubahan warna pada formulasi disebabkan karena penambahan ekstrak mangrove yang lebih banyak pada setiap formulasi.

\subsubsection{Tipe Krim}

Pengujian tipe krim dilakukan untuk mengetahui tipe basis krim yang baik, karena akan berpengaruh terhadap pelepasan bahan aktif dari basisnya. Hasil uji tipe emulsi krim semua sediaan mempunyai tipe emulsi minyak dalam air (M/A) karena bahan aktif bersifat non polar maka afinitas bahan aktif dan basis kecil sehingga pelepasan bahan aktif semakin mudah.

\subsection{3. pH}

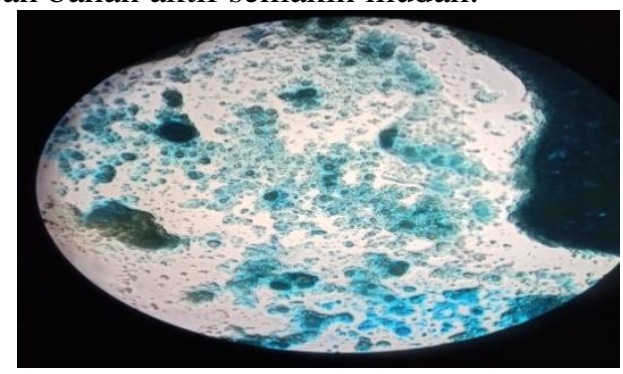

Gambar 1. Hasil Uji Tipe Krim

Uji pH dilakukan untuk mengetahui tingkat kenyamanan dari sediaan agar sesuai dengan $\mathrm{pH}$ sediaan topikal. Hasil uji $\mathrm{pH}$ dari krim ekstrak kulit batang mangrove memiliki rata-rata $\mathrm{pH}$ yaitu 6 . Dimana nilai ini memenuhi standar $\mathrm{pH}$ kulit. Jika krim dibawah $\mathrm{pH} 4.5$ krim dapat mengiritasi kulit dan jika $\mathrm{pH}$ krim diatas 6.5 maka krim bersifat basa yang dapat menimbulkan kulit kering dan bersisik. Berdasarkan persyaratan SNI 16-4954-1998 tentang rentang $\mathrm{pH}$ sediaan krim yang memenuhi persyaratan yaitu 3.5-8. Hasil dalam pengujian ini sesuai yang diharapkan, dimana ketiga sediaan tersebut memenuhi syarat uji $\mathrm{pH}$ yang baik dan tidak menimbulkan iritasi pada kulit.

\subsubsection{Viskositas}


Pengukuran viskositas dilakukan untuk memastikan tingkat kekentalan sediaan krim yang sesuai untuk penggunaan topikal. Hasil viskositas dari sediaan krim dapat dilihat pada tabel IV.

Tabel IV. Hasil Viskositas Krim.

\begin{tabular}{cc}
\hline Formulasi & Viskositas cps \\
\hline F1 & 28500 \\
F2 & 28750 \\
F3 & 29000 \\
\hline
\end{tabular}

Dalam pengujian viskositas menggunakan alat viskometer dengan spindel no 4 kecepatan $30 \mathrm{rpm}$ dan menggunakan faktor kali 200. Persyaratan viskositas yang baik pada sediaan semi solid adalah sebesar 4000-40.000 cps [18] dan syarat SNI No 16-4399-1996 berada dalam kisaran 2000-50.000. Hasil pengujian yang telah dilakukan diketahui bahwa semua formulasi sediaan memenuhi standar yaitu dalam rentang 4000-40.000 cps. Nilai viskositas yang dihasilkan sediaan dapat mempengaruhi daya sebar sediaan ketika diaplikasikan ke kulit. Ekstrak mangrove dapat meningkatkan jumLah serat polimer yang menyebabkan semakin banyak cairan yang tertahan dalam krim sehingga dapat digunakan sebagai peningkat viskositas.

\subsubsection{Daya lekat}

Uji daya lekat bertujuan untuk mengetahui berapa lama krim dapat melekat pada bagian kulit. Hasil uji daya lekat dapat dilihat pada tabel V.

Tabel V. Hasil Uji Daya Lekat.

\begin{tabular}{cc} 
Tabel V. Hasil Uji Daya Lekat. \\
\hline F1 & 2,75 \\
F2 & 3,52 \\
F3 & 4,99 \\
\hline
\end{tabular}

Syarat waktu daya lekat yang baik untuk sediaan topikal adalah tidak kurang dari 4 detik. [19]. Daya lekat dari ketiga formulasi ada yang sudah memenuhi persyaratan daya lekat yaitu pada F3 lebih dari 4 detik. Sedangkan pada F1, F2 belum memenuhi syarat uji daya lekat yang baik.

Tahapan analisis statistik yaitu uji normalitas nilai viskositas dari krim ekstrak kulit batang mangrove Avicenia marina dengan menggunakan SaphiroWilk dan Levene's test. Levene's test. langkah awal yang dilakukan yakni test normalitas, dimana hasil dari normalitas $>0,05$ artinya bahwa dari ketiga formulasi tersebut sediaan normal. Kemudian dilanjutkan dengan test homogenitas dimnana hasil ini 0,11>0,05, artinya dari ketiga formulasi tersebut diperoleh data homogen. Maka dapat diilakukan uji One Way ANOVA. Hasil yang diperoleh dari uji One Way ANOVA menunjukkan signifikansi 0,000 $<0,05$ artinya adanya perbedaan yang nyata (signifikan) pada masing-masing sedian.

\subsubsection{Daya sebar}

Uji daya sebar sediaan dilakukan untuk mengetahui besarnya gaya yang diperlukan sediaan krim untuk mengetahui kemampuan menyebar krim pada saat dioleskan di kulit. Hasil uji daya sebar dapat di lihat pada tabel VI.

Tabel VI. Hasil Dari Uji Daya Sebar.

\begin{tabular}{cc}
\hline Formulasi & Rata-rata Daya sebar $(\mathbf{c m})$ \\
\hline F1 & 3.14 \\
F2 & 2.7 \\
F3 & 2.66 \\
\hline
\end{tabular}

Daya sebar yang baik membuat kontak antara krim dan kulit menjadi lebih luas sehingga zat aktif lebih cepat terabsorsi. Syarat uji daya sebar untuk sediaan topikal sekitar 5- $7 \mathrm{~cm}$ [19]. Sediaan krim diharapkan memiliki kemampuan menyebar yang mudah saat diaplikasikan ke kulit sehingga sediaan mudah 
digunakan. Hasil dari ke tiga formulasi yaitu F1, F2 dan F3 belum memenuhi persyaratan uji daya sebar untuk sediaan topikal.

Tahapan analisis statistik yaitu uji normalitas nilai viskositas dari krim ekstrak kulit batang mangrove Avicenia marina dengan menggunakan SaphiroWilk dan Levene's test. langkah awal yang dilakukan yakni test normalitas, dimana hasil dari normalitas $>0,05$ artinya bahwa dari ketiga formulasi tersebut sediaan normal. Kemudian dilanjutkan dengan test homogenitas dimnana hasil ini $0,427>0,05$, artinya dari ketiga formulasi tersebut diperoleh data homogen. Maka dapat diilakukan uji One Way ANOVA. Hasil yang diperoleh dari uji One Way ANOVA menunjukkan signifikansi $0,000<0,05$ artinya adanya perbedaan yang nyata (signifikan) pada masing-masing sedian. Tujuan uji ANOVA yaitu untuk mengetahui apakah terdapat perbedaan rata-rata pada masing-masing formulasi sediaan krim ekstrak kulit batang mangrove (Avicennia marina).

\subsubsection{Uji Aktivitas Antibakteri}

Uji aktivitas antibakteri ini untuk mengetahui evektifitas dari sediaan krim ekstrak kulit batang mangrove Avicennia marina. Hasil uji aktifitas antibakteri dapat dilihat pada tabel VII.

\begin{tabular}{cc}
\multicolumn{2}{c}{ Tabel VII. Hasil Dari Uji Aktivitas Antibakteri. } \\
\hline Formulasi & $\begin{array}{c}\text { Rata rata Daya hambat bakteri } \\
(\mathbf{m m})\end{array}$ \\
\hline F1 & 15,1 \\
F2 & 17,6 \\
F3 & 19,4 \\
\hline
\end{tabular}

Hasil dari penelitian zona hambat yang terdapat pada tabel VII, dapat dilihat bahwa ekstrak kulit batang mangrove Avicennia marina dapat menghambat pertumbuhan bakteri Staphylococcus aureus. Hasil F1 (15,1 mm), F2 (17,6 mm), dan F3 $(19,4 \mathrm{~mm})$ dapat digolongkan zona hambat kuat karena memiliki zona hambat 15-20 mm. Hasil uji aktivitas antibakteri sediaan krim dapat dilihat pada Gambar 2.

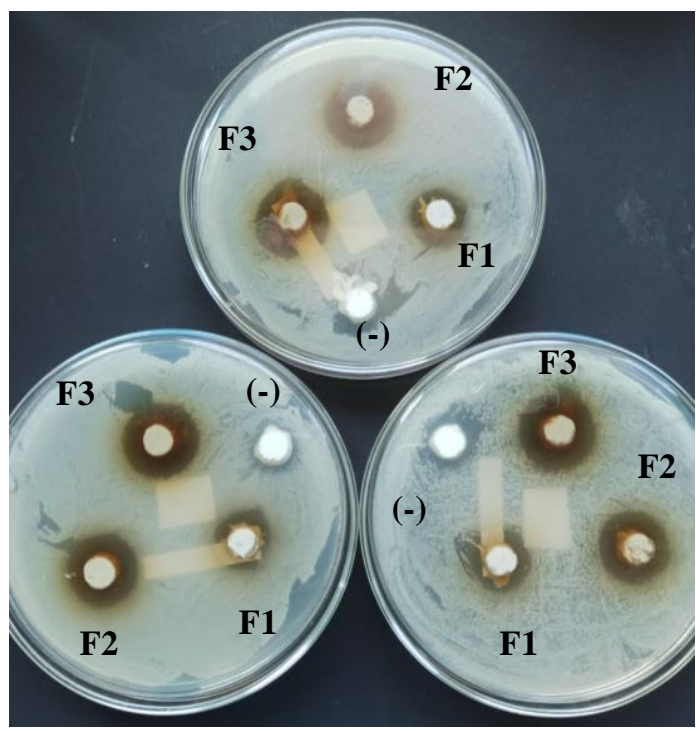

Gambar 2. Hasil Uji Aktivitas Antibakteri Sediaan Krim

\section{Keterangan:}

$(-) \quad=$ Kontrol Negatif (Basis Krim)

F1 = Formula 1 (Ekstrak $5 \%)$

$\mathrm{F} 2=$ Formula $2($ Ekstrak $10 \%)$

$\mathrm{F} 3=$ Formula 3 ( Ekstrak 15\%) 
Tahapan analisi statistik yaitu uji normalitas nilai viskositas ketiga formulasi dari krim ekstrak kulit batang mangrove Avicennia marina dengan menggunakan Saphiro-Wilk. Dan Levene's test langkah awal yang dilakukan yakni test normalitas, dimana hasil dari normalitas F1 dan F2 $0,000<0,05$, artinya data tidak normal, sedangkan F3 1,00 >0,05 artinya diperoleh data normal. Maka tidak dapat diilakukan uji One Way ANOVA. Jadi dilakukan uji Kruskal-Wallis. Uji Kruskal-Wallis merupakan uji non parametrik yang dapat digunakan untuk menguji perbedaan yang signifikan lebih dari 2 kelompok dan uji ini hampir mirip dengan uji ANOVA, namun data yang diuji tidak harus memiliki varian yang sama (homogen). Hasil yang diperoleh dari uji KruskalWallis menunjukkan signifikanis $0,014<0,05$ artinya adanya perbedaan yang nyata (signifikan) pada masing-masing sedian.

\section{KESIMPULAN}

Adanya pengaruh konsentrasi ekstrak kulit batang mangrove terhadap sifat fisik sediaan krim antibakteri, dilihat dari organolptis, homogenitas, tipe krim, $\mathrm{pH}$, daya lekat dan daya sebar. Formulasi yang terbaik adalah Formula 1 dengan konsentrasi ekstrak 5\%. Pengaruh perbedaan konsentrasi ekstrak kulit batang mangrove terhadap aktivitas sediaan krim antibakteri menunjukkan rata-rata diameter zona hambat bakteri berbeda pada F1 $(15,1)$, F2 $(17,6)$ dan F3 $(19,4)$. Semua formulasi sediaan digolongkan zona hambat kuat karena memiliki zona hambat $15-20 \mathrm{~mm}$.

\section{DAFTAR PUSTAKA}

[1] Dharmawan, I. W. E., \& Pramudji. (2014). Panduan Monitoring Status Ekosistem Mangrove (Issue 1).

[2] Mahmiah, Giman, Aminah, N,S., Tanjung, Mulyadi. (2016). AntioxidantActivity of Methanol Ekstracts From The Stem Bark Of Mangrove Plants Rhizophora mucronata. Surabaya : Pracceding ICMHS 2016

[3] Prabhu, V. V., \& Guruvayoorappan, C. (2012). Phytochemical Screening Of Methanolic Extract Of Mangrove Avicennia marina ( Forssk .) Vierh. Pelagia Research Library Des Phamacia Sinica, 3(1), 64-70.

[4] Yunita, E., Rinanda, A. A., Amalia, S., \& Habibah, N. (2019). Pengaruh Penggunaan Karbopol Dan CMC-Na Terhadap Sifat Fisik ( Musa paradisiaca var sapientum) The Effect Of Carbopol And CMC-Na To Physical Properties In Lotion Formulation Of Ambon Banana' S Peel Extract ( Musa paradisiaca var sapientum ). 4(1), 8-14.

[5] Budiarto, Widi., Rochmah, Nikmah Nuur., Setiyabudi, Lulu, Formulasi Sediaan Nanoemulsi Ekstrak Daun Mangrove Avicennia Marina Dengan Virgin Coconut Oil Sebagai Fase Minyak, Jurnal Ilmiah Jophus : Journal of Pharmacy UMUS, Vol. 2 No. 01, Agustus 2020.

[6] Renaldi, Rozirwan, \& Ulqodry, T. Z. (2018). Bioaktivitas Senyawa Bioaktif Pada Mangrove Avicennia Yang Diambil Dari Pulau Payung Dan Tanjung Api-Api The Bioactivity Of Bioactive Compound In Mangrove Avicennia marina And Bruguiera gymnorrhiza As Antibacterial From Payung Island And Tanjung Api-Api. 10(1), 7380.

[7] Kurnianingsih, Dewi., Setiabudi, Lulu., Tajudin, Tatang, Uji Efektivitas Sediaan Krim Kombinasi Ekstrak Daun Bakau Hitam (Rhizophora Mucronata) Dan Jeruk Purut (Citrus Hystrix) Terhadap Bakteri Staphylococcus Aureus, Jurnal Ilmiah Jophus : Journal of Pharmacy UMUS, Vol. 2 No. 01, Agustus 2020. 
[8] Rostinawati, T. (2010). Aktivitas Antibakteri Ekstrak etanol Bunga Rosella (Hibicus sabdariffa L. ) Terhadap Escherichia Coli, Salmonella typhi, dan Sthaphylococcus aureus Dengan metode Difusi Agar. Fakultas Farmasi. Universitas padjadjaran. Jatinangor.

[9] Prihanto., A., Firdaus, M\& Nurdiani, R. (2011). Penapisan Fitokimia dan antibakteri ekstrak metanol mangrove (Excoocaria agallocha) dari Muara Sungai Prong.

[10] Depkes RI. 1995. Materia Medika Indonesia. Jilid VI. Jakarta: Departemen Kesehatan Republik Indonesia. Hal 334, 336, 337.

[11] Astuti, M.S. (2010). Skrining fitokimia dan uji aktivitas antibiotika ekstrak etano daun, batang, dan umbi tanaman binahong (Auredera cordifolia (Ten Steens). Universitas malaysia Pahang: malaysia.

[12] Wulandari, (2017). Formulasi Dan Uji Aktivitas Antibakteri Staphylococcus Epidermidis Sediaan Mikroemulsi Ekstrak Daun Kersen (Muntingiacalabura Linn ) Dengan Fase Minyak Ispropil Miryristate.

[13] Safitri,N A., Puspita, O.E., and Yurina, V., (2014). Optimasi Formula Sediaan Krim Ekstrak Stroberi (Fragaria $x$ Ananassa) Sebagai Krim Anti Penuaan. Majalah Kesehatan FKUB, 1 (4), 235-246.

[14] Lachman L, Herbert, A.L \& Joseph, L. K., (2008). Teori Dan Praktek Industri Farmasi Edisi III , 1119-1120, Penerbit Universitas Indonesia, Jakarta

[15] Widjajasaputra, A.J. and Widyastuti, T.E.W. (2017). Internasional Food Research Journal 24(3): 1199-1203.

[16] Latifah, (2015). Identifikasi Golongan Senyawa Flavonoid Dan Uji Aktivias Antioksidan Pada Ekstrak Rimpang Kencur ( Kaemferia galanga L ) Dengan Metode DPPH (1,1-difenil,2 fikrilhidrazil).

[17] Saefuddin A, Rahayu, Yuda Hilwan. (2011). Standarisasi Bahan Obat Alam. Graha Ilmu. Yogyakarta. Hal 1-22.

[18] Wasiataamaja, S.M. (1997). Penentuan ilmu Kosmetik Medik. Jakarta: UI press

[19] Ulen, S., banne, Y., \& Suatan, R. (2012). Pembuatan Salep Anti Jerawat Dari Ekstrak Rimpang Temulawak (Curcuma xanthorriza Robx). Jurnal Ilmiah Farmasi, 3(2), 4549 